\title{
Peertechz
}

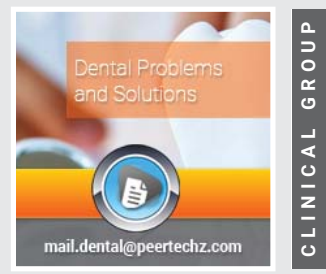

Research Article

\section{Dental caries experience of 12 year old children from Resen municipality}

\author{
Nonkulovski Zoran', Ambarkova Vesna ${ }^{2,3 *}$, Jankulovska Mira ${ }^{2,3}$, \\ Krmzova Tina', Arjeta Sulejmani' ${ }^{1}$ and Violeta Nonkulovska ${ }^{4}$ \\ ${ }^{1}$ Interns at the Department for Pediatric and Preventive Dentistry, Faculty of Dental Medicine, \\ University Ss.Cyril and Methodius, Skopje, Republic of North Macedonia \\ ${ }^{2}$ Department for Preventive and Pediatric Dentistry, Faculty of Dentistry, University Ss.Cyril \& \\ Methodius -Skopje, Republic of Macedonia \\ ${ }^{3}$ University Dental Clinic Center Ss.Pantelejmon, Skopje, Republic of North Macedonia \\ ${ }^{4} \mathrm{PHI}$ Health Center Resen, Republic of North Macedonia
}

Received: 21 December, 2021

Accepted: 18 January, 2022

Published: 19 January, 2022

*Corresponding author: Ambarkova Vesna, Ph.D. MSc, DDS, Department of Pediatric and Preventive Dentistry, University St. Cyril and Methodius, Faculty of Dental Medicine, Mother Theresa 17 University Dental Clinic Center Sv.Pantelejmon, Skopje 1000, Republic of North Macedonia, Tel: ++38970686333; E-mail: vesna. ambarkova@gmail.com; vambarkova@stomfak.ukim. edu.mk

ORCID: https://orcid.org/0000-0001-8010-5125

Keywords: Children; Dental caries; Epidemiology

Copyright License: (c) 2022 Zoran N, et al. This is an open-access article distributed under the terms of the Creative Commons Attribution License, which permits unrestricted use, distribution, and reproduction in any medium, provided the original author and source are credited.

https://www.peertechzpublications.com

\section{Check for updates}

\section{Abstract \\ Introduction: Despite scientific advances and the fact that caries is preventable, dental caries are still the most prevalent dental affliction of childhood within developing countries.}

Aims: The aim of this study was to assess dental caries in 12-year-old children from Resen municipality suited at the Pelagonia region of the Republic of North Macedonia.

Methods: In this cross-sectional study, primary school children from sixth grades ( $\mathrm{N}=158$ ) were selected from (5) primary schools from the Resen municipality. The Dental status of the children was evaluated during 2020 year, using the 2013 World Health Organization caries diagnostic criteria for Decayed, Missing and Filled Teeth (DMFT) by 2 calibrated examiners. Data obtained during the survey was stored in a database and statistical analysis with SPSS v.21(IBM). Using the t-test, the data were tested for possible statistically significant differences. A p value $<0.05$ was considered statistically significant. Parental consent was obtained for each child.

Results: The total number of children ( $\mathrm{N}=158)$ in the sample was comprising $71(44.94 \%)$ females and $87(55,06 \%)$ males. The mean DMFT score of the whole sample was $1.82 \pm 1.82$. The average DMFT score within female children was $1.70 \pm 2.03$, while within male children was $1.92 \pm 1.64$. The average DMFT score within children from urban area was $1.71 \pm 1.65$, while within children from rural area was $1.94 \pm 1.98$. The prevalence of caries free children was $36.08 \%$.

Conclusion: The prevalence of dental caries within 12-year-old children from the Resen municipality and its surrounding was $63.92 \%$.

\section{Introduction}

Despite the long-term implementation of many prevention programs and measures, dental caries is still a major public health problem in many developing countries. Approximately 3.6 billion people ( $48 \%$ of the population) worldwide have dental caries in their permanent teeth [1].

Numerous epidemiological studies are conducted daily around the world to determine the prevalence of dental caries and the average DMFT index in school children and adolescents [2-5].

Oral health of children is one of the essential elements for general health, especially for the growth and development in childhood. Therefore, everything that is not protected by preventive measures in the initial stage of any oral pathology further could not be compensated anymore. This maxim is especially true for caries and periodontal changes, as elements of oral health that are most common in everyday pathology. 
Macedonia was part of Yugoslavia until 1991. The two European countries (Albania and Yugoslavia) that still had no data about the prevalence of dental caries were announced by WHO in the late 1970 [6]. Vrbic V and colleagues from all six republics and the country's two provinces started a pilot study in cooperation with WHO [7]. We was part of that pilot study and the scientific project directed by Nečeva was conducted in four districts (Skopje, Veles, Štip and Ohrid) in the Republic of Macedonia [8]. In the epidemiological study conducted in 1991, the estimated value of the average DMFT index within 12 years old children was 5.22 [9]. So we did not have any information about the average DMFT index within 12-year-old children from Resen municipality.

The municipality of Resen is located in the Prespa Valley, in the southwestern part of the Republic of Macedonia and covers an area of $739 \mathrm{~km} 2$. Divided on land with $562 \mathrm{~km} 2$ and water with $177 \mathrm{~km} 2$, it is a separate spatial unit, which geographically extends around the intersection of the 41st degree GMS and the 21st degree IGD (Figure 1) [10].

According to the 2002 census, there are 16,825 inhabitants in the municipality of Resen, of which $50.3 \%$ are female and 49.7\% are male. Those ethnic groups: Macedonians (76.1\%), Turks (10.7\%), Albanians (9.1\%), Roma (1.1\%) and others, live in the municipality of Resen.

Each epidemiological study serves for planning and improvement of the respective area where it is conducted. So we hope that this study will contribute to the improvement of the oral health of the children from the Resen municipality. Due to outdated and insufficient data on the dental status of 12-year-old children from the municipality of Resen, as well as due to determining the effects of the implemented National Strategy [11], we conducted this examination. The aim of this study was to assess dental caries in 12 year-old children from Resen municipality suited at the Pelagonia region of the Republic of North Macedonia.

\section{Methods}

The sample of this cross-sectional study was 158 school children from sixth grades, attending 2 central and 3 regional primary schools in the Resen city and villages from its surrounding. The names of the schools are: primary school Goce Delcev, Mite Bogorvski, Slavejko Arsov, Braka Miladinovci and Dimitar Vlahov. Children from Resen city and 27 villages are involved in this study. Before the start of the study, we gain permission from the school authorities. Also, we obtained consent from the parents of the children involved in the study.

We used cluster sampling and all classes (sixth grades) children were included in the study because it was more economically taking in mind our constraints of financial resources.

Ethical approval was obtained from the Ministry of health. The children from 12 years old are with all permanent teeth erupted, except third molars, and are suitable for global monitoring of dental caries and international comparisons of dental caries trends.

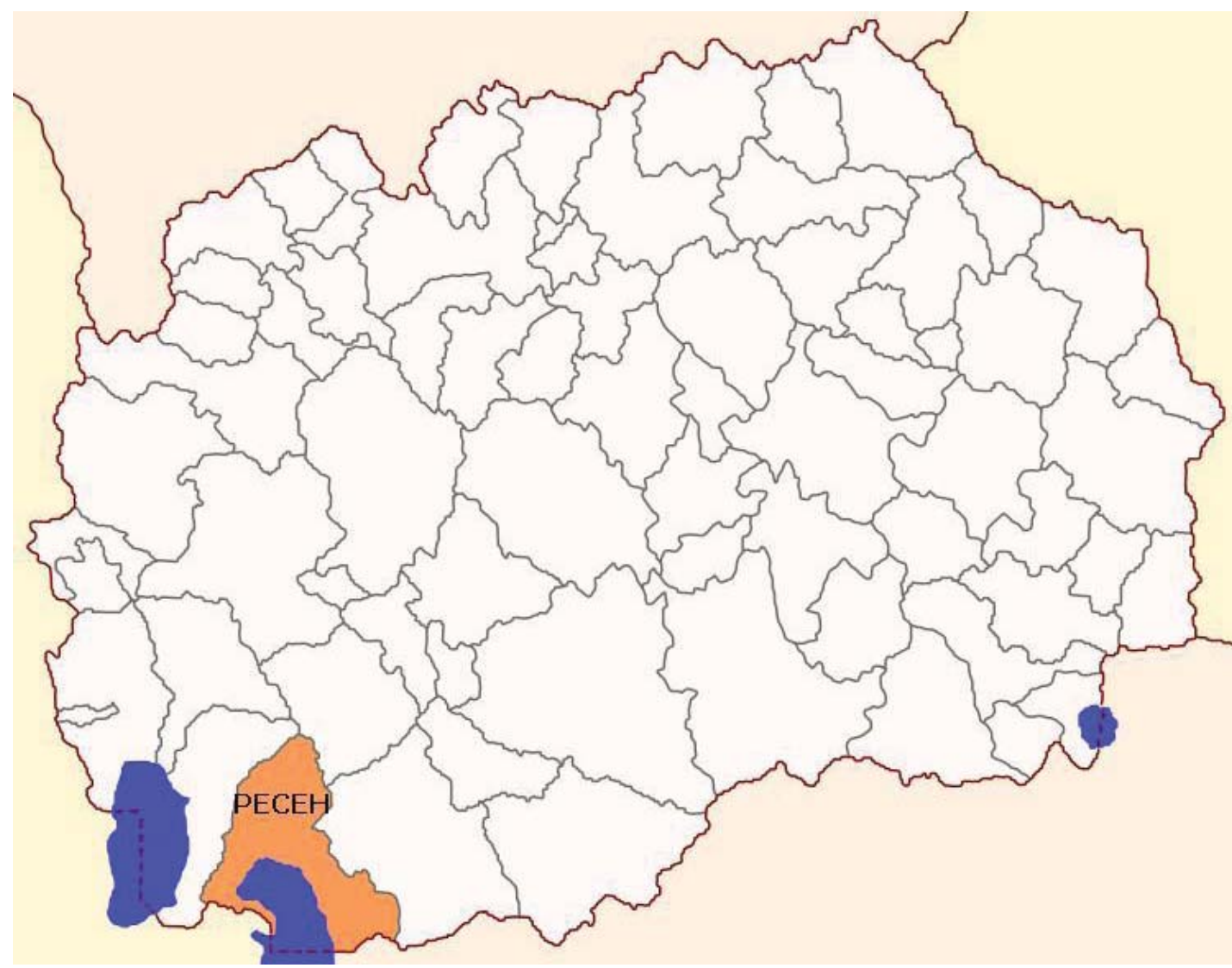

Citation: Nonkulovski Z, Ambarkova V, Jankulovska M, Tina K, Sulejmani A, et al. (2022) Dental caries experience of 12 year old children from Resen municipality. 
Data were collected by means of clinical examinations in daylight using plain dental mirrors and sharp explorers, which took place in pediatric dental sector of the Health Center Resen. The examinations focus on the presence of caries and was diagnosed at the cavitation level. The caries experiemce of each child was recorded by counting the components DT, MT, and FT of the DMFT index (Decayed, Missing, and Filled Teeth), following the World Health Organisation (WHO) caries diagnostic criteria [12]. Fluoride levels in the drinking water was low 0.07 from the water supply from Resen city. The examiners were calibrated prior to the surveys in order to obtain consistency indices for recording caries.

Data obtained during the survey was stored in a database and statistical analysis with SPSS V.21(IBM). Using the t-test, the date were tested for possible statistically significant differences. A p value $<0.05$ was considered statistically significant.

\section{Results}

Statistical data that was collected were from primary school children from the Resen municipality. For each child following data was recorded: age, gender(male and female), area (urban or rural) and city/village, number of Decayed Teeth (DT), number of Missing Teeth (MT) and number of Filled Teeth (FT). The DMFT index, the sum of DT, MT and FT, was calculated and recorded for each child. The size of the statistical sample was 158 . In Table 1 the mean value of DMFT index foe the whole sample is given (average DMFT $=1.82 \pm 1.822$ ).

In Table 2 the distribution of male and female children from studied sample is given and gender wise comparison of average DMFT of 12-yer children. The average DMFT of female children is $1.92 \pm 1.637$, while average DMFTof male children is $1.70 \pm 2.031$. $\mathrm{T}$-test was performed to see if there are differences in average DMFT index between the male and female children. The value Sig. (2-tailed) 0.471 shows that there is no statistical significant difference between mean DMFT of male and female 12-year old children.

In Table 3 the distribution of children living in the rural and urban area is given and comparison of their mean DMFT. The mean DMFT of children from rural area is $1.94 \pm 1.983$, while the mean DMFT of children from urban area is $1.71 \pm 1.650$. $\mathrm{T}$-test was performed to see if there are differences in average DMFT index between children from urban and rural area. The value Sig. (2-tailed) 0.434 shows that there is no statistical significant difference between mean DMFT of children from urban and rural area.

In Table 4 the comparison of the mean $\mathrm{D}, \mathrm{M}$ and $\mathrm{F}$ component of the DMFT for urban and rural populations was shown. It was not statistically significant, as p-value is more than 0.05 .

The DMFT components, DT, MT and FT were also analyzed. Their mean values, Standard Deviations (SD's) are reported in Table 5. It is important to describe the composition of the DMFT, which allows us to evaluate the level of dental care in the country. Table 5 shows higher mean F score in comparison to D score, which indicates overall population has access to
Table1: Average DMFT of whole group of 12-year children.

\begin{tabular}{|c|c|c|c|c|c|}
\hline \multicolumn{5}{|c|}{ Descriptive Statistics } \\
\hline & $\mathbf{N}$ & Minimum & Maximum & Mean & Std. Deviation \\
\hline DMF & 158 & 0 & 8 & 1.82 & 1.822 \\
\hline
\end{tabular}

Table 2: Gender wise comparison of average DMFT of 12-year children.

\begin{tabular}{|c|c|c|c|c|c|}
\hline & Gender & $\mathbf{N}$ & Mean & Std. Deviation & Std. Error Mean \\
\hline \multirow{2}{*}{ DMF } & Male & 71 & 1.70 & 2.031 & .241 \\
\hline & Female & 87 & 1.92 & 1.637 & .175 \\
\hline t value & & & & Sig. (2-tailed) & \\
\hline-.722 & & & & .471 & \\
\hline
\end{tabular}

Table 3: Area of living wise comparison of average DMFT of 12-year children.

\begin{tabular}{|c|c|c|c|c|c|}
\hline & Locality & N & Mean & Std. Deviation & Std. Error Mean \\
\hline \multirow{2}{*}{ DMF } & Urban & 79 & 1.71 & 1.650 & .186 \\
\cline { 2 - 6 } & Rural & 79 & 1.94 & 1.983 & .223 \\
\hline t value & & & & Sig. (2-tailed) & \\
\hline-0.785 & & & & 0.434 & \\
\hline
\end{tabular}

Table 4: DT, MT, FT scores for children living in urban and rural area separately.

\begin{tabular}{|c|c|c|c|c|c|c|c|}
\hline \multicolumn{6}{|c|}{ Group Statistics } & \multirow{2}{*}{ t value } & \multirow{2}{*}{ Sig. (2-tailed) } \\
\hline & Locality & $\mathbf{N}$ & Mean & Std. Deviation & Std. Error Mean & & \\
\hline \multirow{2}{*}{ D } & Urban & 79 & .47 & .814 & .092 & \multirow{2}{*}{-1.026} & \multirow{2}{*}{.307} \\
\hline & Rural & 79 & .65 & 1.301 & .146 & & \\
\hline \multirow{2}{*}{ M } & Urban & 79 & .01 & .113 & .013 & \multirow{2}{*}{1.000} & \multirow{2}{*}{.320} \\
\hline & Rural & 79 & 0.00 & 0.000 & 0.000 & & \\
\hline \multirow{2}{*}{$\mathrm{F}$} & Urban & 79 & 1.23 & 1.414 & .159 & \multirow{2}{*}{-.271} & \multirow{2}{*}{.787} \\
\hline & Rural & 79 & 1.29 & 1.520 & .171 & & \\
\hline
\end{tabular}

Table 5: DT, MT, FT scores for the total sample.

\begin{tabular}{|c|c|c|c|c|c|}
\hline \multicolumn{5}{|c|}{ Descriptive Statistics } \\
\hline & N & Minimum & Maximum & Mean & Std. Deviation \\
\hline D & 158 & 0 & 6 & .56 & 1.085 \\
\hline M & 158 & 0 & 1 & .01 & .080 \\
\hline F & 158 & 0 & 6 & 1.26 & 1.464 \\
\hline
\end{tabular}

dental treatment. And they have positive attitude towards dental treatment. The ratio of D/DMFT gives an indication of treatment need. In the current study, this ratio indicated that untreated caries was responsible for $0.56(56.0 \%)$ of the DMFT index Figures 2,3.

\section{Discussion}

The study aimed to assess the dental caries experience in school children from the Resen municipality, which is located in the Pelagonia Region of the Republic of North Macedonia. The purpose of the study was to help planning preventive programmes and to serve as a baseline for future evaluation of preventive measures in this municipality. The eight regions in our country are Skopje, Vardar, Pelagonia, East, Southwest, Polog, Northeast and Southeast region with their own characteristics (environmental, organizational, socioeconomic, ethnic, etc.), which undoubtedly have an impact on lifestyle and health, which includes oral health. On the territory of the municipality of Resen, one specialist in pediatric and preventive dentistry and one general dentist work in the state health sector, while in the private sector there are one 


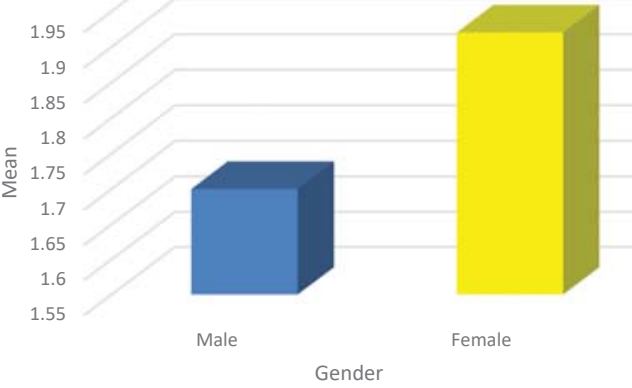

Figure 2: Gender wise comparison of mean DMFT for the study population of 12 year children.

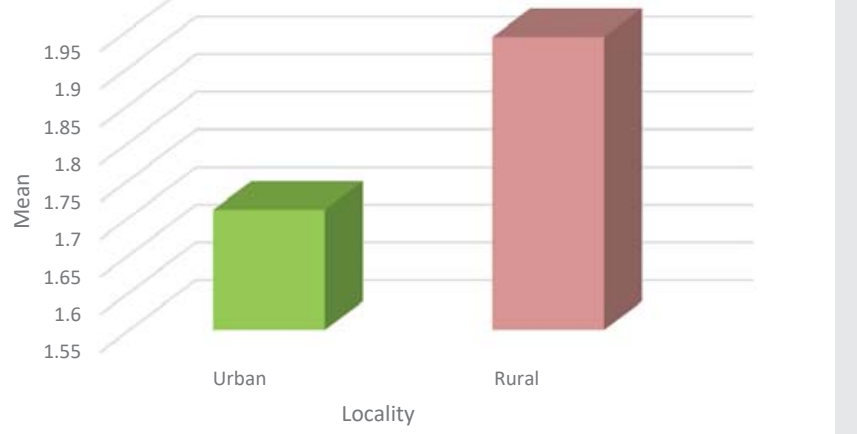

Figure 3: Locality wise comparison of mean DMFT for the study population of 12 year children.

orthodont, one specialist in prosthodontics and 12 general dentists.

The overall mean DMFT was 1.82 and can be classified as low dental caries experience. The caries-free prevalence was $36.08 \%$. and the caries prevalence was $63.92 \%$. Comparing the results from this study (DMFT=1.82) with the cross-section study conducted in 2013 by Ambarkova, et al. [2] within 12 years old children from Eastern region (DMFT=3.467) it is evident that the DMFT index show tendency to decrease. We believe that this decrease in the average DMFT index is partly due to the increasing use of sealing of the occlusal surfaces on the first permanent molars by the dental teams in charge of the implementation of the National Strategy for Prevention of Oral Diseases in children aged 0 to 14 years [11]. In the resent study conducted in Croatia by Lešić $\mathrm{S}$ et all the mean DMFT was 3.4 within 12-year-old children [13]

The caries prevalence in the Resen municipality from Pelagonia region in our country is $63.92 \%$, which is similar with caries prevalence in the 12 years old children from Eastern region $(78.79 \%)$ in our country, and $61 \%$ (50-72\%) for permanent dentition in children from 9 countries from Eastern Mediterranean Region [14]. In the meta analysis conducted by Teshome et al in Africa, the prevalence of dental caries was 65.2\% in Eritrea, 57.8\% in Sudan, 30.7\% in Tanzania [15].

There was no gender difference in the mean DMFT but the average DMFT of the 12-year olds in Resen municipality our country was higher in females (1.92) than males (1.70\%). Also, there was no difference in the mean DMFT in the children from rural and urban area, but the mean DMFT of the 12-year olds from the rural area was higher (1.94) than within children from urban area (1.71). Resen city belongs in the group of settlements from R. Macedonia which are with a lack of fluoride in drinking water $(<0.2 \mathrm{ppmF})$. Public water supply from the Resen municipality has 0.07 ppm F [16]. Urban and rural areas have their own specifics, but it is evident that there are now smaller differences between them, at least in terms of oral health. The existence of good communication between urban and rural areas has reduced the differences in both lifestyle and in the diet of the population.

The mean DMFT index of 12-year-old children during the epidemiological study conducted in 1991 was with the lowest value in Veles city 3.48 and with the highest 6.55 in the city of Skopje [9]. Oral health epidemiological studies despite their limitation must be conducted periodically [17].

Prevalence of dental caries among 12-year-old children from Resen municipality (63.92\%) which was lower in comparison with our previous research within 15-year-old students from Vardar region (90.55\%) [5] and within 12-yearold children from Eastern region (78.79\%) [2].

\section{Conclusion}

The prevalence of dental caries within 12-year-old children from the Resen municipality and its surrounding was $63.92 \%$. However, we need to work on improving it. Oral health of children is a concern not only of pediatric dentists but also of the wider community.

\section{Acknowledgments}

The authors would like to thank all directors of primary schools, parents and children for their participation and support to conduct the school-based oral health survey in Resen municipality.

\section{Ethical considerations}

Authors obtained the Ethics Committee agreement (no. 471) for conducting this investigation among children from Resen municipality.

\section{References}

1. Global, regional, and national incidence, prevalence, and years lived with disability for 354 diseases and injuries for 195 countries and territories, 19902017: a systematic analysis for the Global Burden of Disease Study 2017. Lancet 392: 1789-8583. Link: https://bit.ly/3nB0uOK

2. Ambarkova V, Ivanova V (2014) Dental Caries Experience among primary school children in the Eastern Region of the Republic of Macedonia. Ora Health Dent Manag 13: 1-7. Link: https://bit.ly/3AaDfQs

3. Batra M, Ambarkova V, Stevanovic M, Jankulovska M, Shah AF, et al. (2015) Dental caries experience among 12 year old school children from Macedonia and India. J Dent Probl Solut 2: 044-047. Link: https://bit.ly/3fwKjxt

4. Ambarkova V, Panova O. (2015) The Pilot study about dental caries experience among 15-years old (secondary school) children in the Southeast region of the Republic of Macedonia. Medicus 20: 253-260.

5. Ambarkova V, Jankulovska M, Arian D, Glavina D, Soleva A.(2014) Dental caries experience among secondary school children in the Vardar region of the Republic of Macedonia. Oral Health Dent Manag 13: 805-810. Link: https://bit.ly/3AawazJ 
6. Vrbic V, Vrbic M, Petersen EP (2020) Epidemiology of Dental Caries and Disease Prevention Among 12-Year-Olds in Slovenia Over Thirty Years (19872017). Oral Health Prev Dent 18: 185-196. Link: https://bit.ly/3KwRtAj

7. Vrbic V, Vulović M, Rajić Z, Topić B, Tatić E, et al. (1988) Oral health in SFR Yugoslavia in 1986. Community Dent Oral Epidemiol 16: 286-288. Link: https://bit.ly/3nvhfef

8. Neceva L, Carcev M, Nakova M, Dimitrovski V, Zuzelova M, et al. (1993) The Condition of Oral Health and Needed Care among population in Macedonia from four districts. Macedonian Dental Review 17: 89-95.

9. Neceva L, Carcev M, Nakova M, Dimitrovski V, Zuzelova M, et al. (1992) Oral Health Condition in population from SR Macedonia and Required treatment. Macedonian Dental Review 16: 38-46. Link: https://bit.ly/33JJPkW

10. Regions of the Republic of North Macedonia (2021) State Statistical Office of the Republic of Macedonia. Link: https://bit.ly/3nztCWF

11. National strategy for prevention of oral diseases in children from 0 to 14 years of age in the Republic of Macedonia for the period from 2008 to 2018 (2007) Ministry of Health. Republic of Macedonia, Skopje. Link: https://bit.ly/3fB44nM
12. WHO (2013) Oral Health Surveys: Basic Methods. (5th Edn). Geneva: World Health Organization. Link: https://bit.ly/3AhmQtS

13. Lešić S, Dukić W, Šapro Kriste Z, Tomičić V, Kadić S (2019) Caries prevalence among schoolchildren in urban and rural Croatia. Cent Eur J Public Health 27 256-262. Link: https://bit.ly/3GGOFxX

14. Kale S, Kakodkar P, Shetiya S, Abdulkader R (2020) Prevalence of dental caries among children aged 5-15 years from 9 countries in the Eastern Mediterranean Region: a meta-analysis. East Mediterr Health J 26: 726-735. Link: https://bit.ly/3KilAuZ

15. Teshome A, Muche A, Girma B(2021) Prevalence of Dental Caries and Associated Factors in East Africa, 2000-2020: Systematic Review and MetaAnalysis. Front Public Health 9: 645091. Link: https://bit.ly/3nB0XjP

16. Ambarkova V, Topitsoglou V, Iljovska S, Carcev M (2005) Natural fluoridated drinking water from the Republic of Macedonia. Mac Dent Review 29: 177-182. Link: https://bit.ly/3FCRdfj

17. Frencken J(2018) Caries Epidemiology and Its Challenges. Monogr Oral Sc 27: 11-23. Link: https://bit.ly/3qBqL18
Discover a bigger Impact and Visibility of your article publication with Peertechz Publications

\section{Highlights}

* Signatory publisher of ORCID

* Signatory Publisher of DORA (San Francisco Declaration on Research Assessment)

* Articles archived in worlds' renowned service providers such as Portico, CNKI, AGRIS, TDNet, Base (Bielefeld University Library), CrossRef, Scilit, J-Gate etc.

* Journals indexed in ICMJE, SHERPA/ROMEO, Google Scholar etc.

* OAI-PMH (Open Archives Initiative Protocol for Metadata Harvesting)

* Dedicated Editorial Board for every journa

* Accurate and rapid peer-review process

* Increased citations of published articles through promotions

* Reduced timeline for article publication

Submit your articles and experience a new surge in publication services (https://www.peertechz.com/submission). 